症 例

術前動注化学療法が奏効した肋骨原発悪性リンパ腫の 1 例

福山第一病院外科

岡本康久八木孝化大江新野橋本雅明

岡山大学第 1 外科

$$
\text { 井上文之上川康明折田蒝三 }
$$

助骨原発の悪性リンパ畽は比較的稀な疾患である，今回，本症を経験したので，文献 的考察を加兄て報告する。

39歳，男性．右背部痛を主訴として来院。胸部 X 線，CT, MRI 上り右第 5 肋骨原発 の悪性腫瘍と診断し, 動注化学療法を行ったところ, 畽場は著明に緶小し, 根治手術が 可能となった。病理組織学的にはびまん性大細胞型悪性リンバ腫であった，全身化学療 法を併用し，衍後10カ月を経過した現在，再発も見られす健在である。

事引用語：骨悪性 リンバ腫, 肋骨原発畽瘍、動注化学療法

はじめに

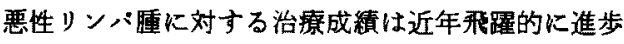
したが，それは正確な臨床病期，病理診断に基ついた 集学的治療によるるのである。節外性リンパ属ははと んどの撼器から発生することが知られているが，骨原 発のすのは極めて稀なことから診断の確定が遅れるこ とが多い. 今回われわれは右第 5 助骨に発生した悪性 リンパ属に対して術前動注化学潦法が奏効し切除し得 たので，若干の文献的考察を加えて報告する.

$$
\text { 症例 }
$$

患者：39歳，男性.

主訴：右背部痛。

家族歴：特記すへきさとなし。

兂往歴：13歳時,急性虫垂资にて虫垂切除，37歲時， 肝譏能障害。

現病歴： 1 年前より時々軽い右背部痛があったが放 置していた。1990年10月下旬より右背部痛，心窝部痛 があり，10月30日に当院を受診した。咳裹，喀痰はな し. 胸部 X 線写真にて異常陰影を認めたため，11月 1 日入院した。

入院時現症：身長 $174 \mathrm{~cm}$, 体重 $64.5 \mathrm{~kg}$. 血代108一58

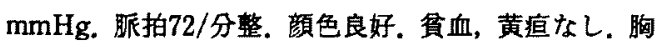

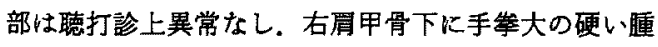
瘤を触知した，表在リンパ節は触知せず。

1991年11月27日受付 1992年 6 月22日採用

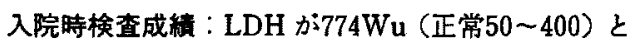
上昇しているほかは異常なく，尰濠マーカーも正常範 囲内であった（表 1 )。

画像診断：胸部 X 線桱査では，右上中肺野に胸壁を 底辺とし胸腔内に突出する辺縁に凹凸のある境界明䝶 な15×6.5cm 大の腫瘤影を諗め, extrapleural sign 陽

\begin{tabular}{|c|c|c|c|}
\hline \multicolumn{2}{|l|}{$[\mathrm{CBC}]$} & \multicolumn{2}{|c|}{ [Serum chemistry] } \\
\hline $\mathrm{RBC}$ & $541 \times 10^{4} / \mathrm{mm}^{3}$ & \multicolumn{2}{|c|}{ T.P $\quad 7.0 \mathrm{~g} / \mathrm{dl}$} \\
\hline $\mathrm{Hb}$ & $16.4 \mathrm{~g} / \mathrm{dl}$ & Alb & $4.2 \mathrm{~g} / \mathrm{dl}$ \\
\hline $\mathrm{Ht}$ & $47 \%$ & $\mathrm{ZTT}$ & $7 \mathrm{Ku}$ \\
\hline WBC & $5,000 / \mathrm{mm}^{3}$ & TTT & $1 \mathrm{Ku}$ \\
\hline St & $3 \%$ & T.Bil & $0.5 \mathrm{mg} / \mathrm{dl}$ \\
\hline Seg & $49 \%$ & GOT & $30 \mathrm{~K}$ \\
\hline Lymp & $39 \%$ & GPT & $26 \mathrm{~K}$ \\
\hline Mono & $5 \%$ & ALP & $8.7 \mathrm{~K}-\mathrm{Au}$ \\
\hline Eosin & $10 \quad 4 \%$ & LAP & $162 \mathrm{G}-\mathrm{Ru}$ \\
\hline Plt 3 & $35.0 \times 10^{4} / \mathrm{mm}^{3}$ & ${ }_{r} \mathrm{GTP}$ & $60 \mathrm{mU} / \mathrm{ml}$ \\
\hline [ESR] 3 & $3 / 1 \mathrm{hr}, 6 / 2 \mathrm{hr}$ & $\mathrm{Ch}-\mathrm{E}$ & $0.8 \Delta \mathrm{pH}$ \\
\hline \multicolumn{2}{|c|}{ [Tumor marker] } & $\underline{\mathrm{LDH}}$ & $774 \mathrm{Wu}_{\uparrow} \uparrow$ \\
\hline AFP & $(-)$ & \multicolumn{2}{|c|}{ [Respiratory function] } \\
\hline CEA & $1.0 \mathrm{ng} / \mathrm{ml}$ & VC & $4.13 \mathrm{~L}$ \\
\hline CA19-9 & $18 \mathrm{U} / \mathrm{ml}$ & $\%$ VC & $102.0 \%$ \\
\hline \multicolumn{2}{|c|}{ [Urinalysis] } & \multirow{2}{*}{\multicolumn{2}{|c|}{$\begin{array}{l}\text { FEV1.0 } \\
\text { FEV1 } 0 \%\end{array}$}} \\
\hline Protein & $(-)$ & & $\% \quad 74.0 \%$ \\
\hline Sugar & $(-)$ & \multicolumn{2}{|c|}{ [ECG] w.n.1. } \\
\hline \multicolumn{4}{|c|}{ Urobilinogen $(+-)$} \\
\hline O.blood & $1-1$ & & \\
\hline
\end{tabular}

表 1 入院時険㚗成绩 
性であった。 また右第 5 肋骨の融解像を認めた(図 1 ).

胸部 CT では，右胸壁後部に第 $4 ， 5 ， 6$ 肋骨にか けて内部は均一で，漫潤珄の骨融解像を伴 $512 \times 7 \mathrm{~cm}$ 大の尰瘤影を認めた（図 2).

MRI では, T2強調画像にて, 右背側の胁骨に一致し て，内部が不整な高信号を示す腫瘤影を認め，外側の 筋肉との境界は明瞭で筋肉への直接漫潤は認められな かった。

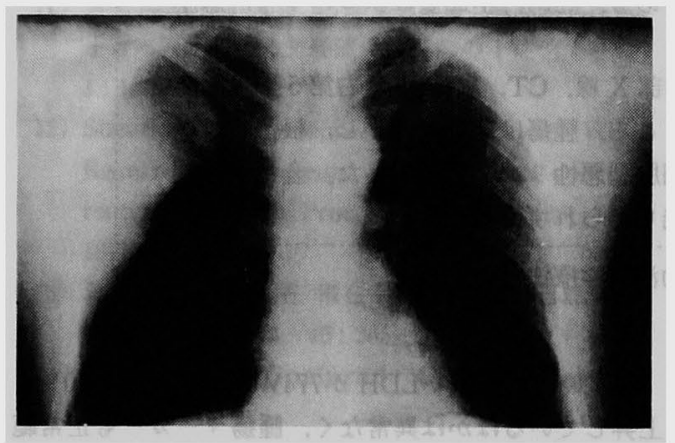

因 1 胸部正面 X 線使

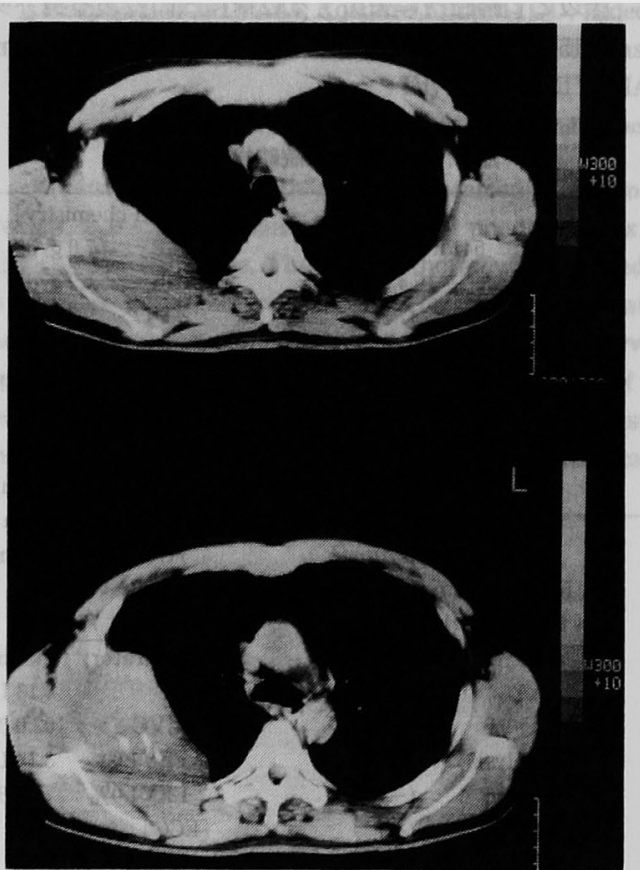

四2胸部 CT 值

骨シンチグラフィーでは，右第 5 肋骨外側の腫瘤が 存在すると思われる部位に RI 集積の低下を認め，そ の周囲の第 4 肋骨から第 6 肋骨に異常集穦像を涩め た.

11月17日に施行した選択的血管造影では，右第 5 助 間動脈を栄養血管とし；腫瘤を取り巻くよらに走行す る細動脈による tumor stainを認めた（図 3)，造影に 引続き，右第 5 助間動脈より Cis-diammine dichloroplatinum (CDDP) $50 \mathrm{mg} と$ Adriamycin (ADR) $10 \mathrm{mg}$ を注入した。動注後17日目の胸部CTでは腫瘤は $11.5 \times 3 \mathrm{~cm}$ と著明に縮小した(図 4 )。縮小率は約 $60 \%$ であった. 12 月 7 日に 2 回目の選択的血管造影を施行 し, 前回と同様に CDDP $50 \mathrm{mg} と \mathrm{ADR} 10 \mathrm{mg}$ を動注 した.

腹部超音波検査，上部消化管造影，注腸造影では異 常を認めなかった。

経皮針生検：組織の挫隇が強く，異型性の強い細胞 は認められたが，組織学的診断はつかなかった。

以上より右第 5 助骨原発悪性腫瘍と診断したが，確 定診断は得られず，1991年 1 月17日手術を施行した。

手征所兒：右後側方切開にて開胸し，右第 4，5，

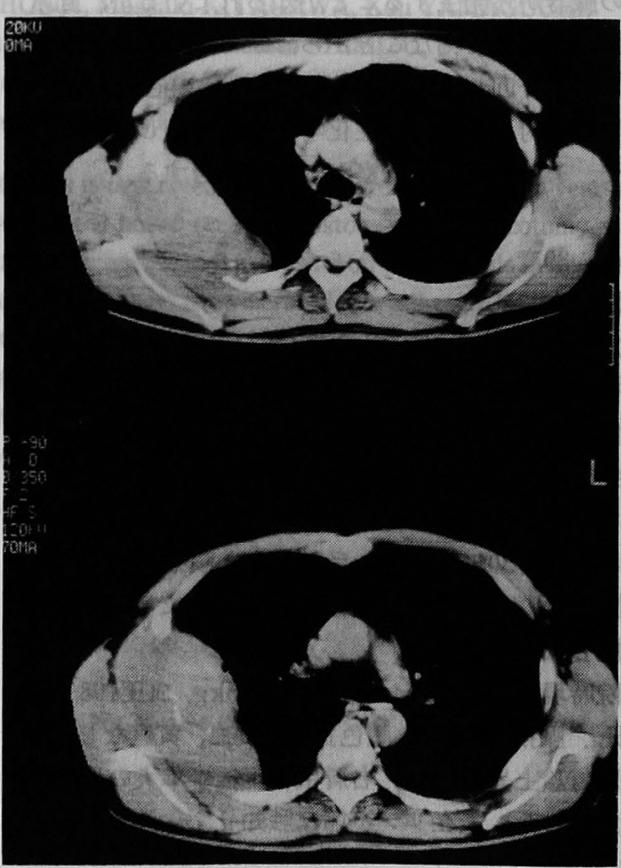




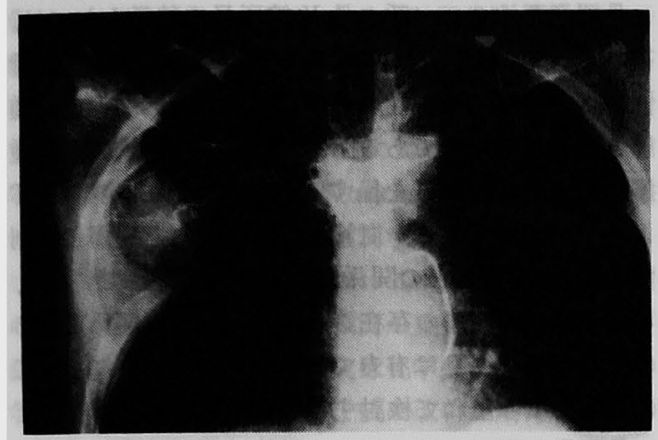

図 3 右籍 5 助间勋脈造影

6 助骨を含めて腫瘍 $(11.0 \times 4.5 \times 3.0 \mathrm{~cm})$ を摘出, 腫

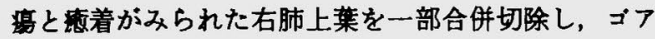
テックスシートを用いて胸壁を再建した。

病理組織所見：肋骨周囲の軟部組織から满側胸膜に かけて，不規則な切れ込みを有する卵円形の核をるち， 胞体の境界が不明瞭な円形ないし多角形細胞が充実性 に增殖しており, 腫湯細胞は, matrixの産生等 osteosarcoma を示唆する分化す特徽的な構造も示さ
なかった（图 5)．免疫組織学的にこれらの細胞は， $\mathrm{LCA}(+), \operatorname{PanB}(+), \mathrm{LN}-1 \mathrm{p}(+) て ゙ あ り$, malignant lymphoma, diffuse large cell type (B) と診断した. 術後経逜：合併症なく順調に回復し，血中 LDH は 術前値774Wuから正常範囲内に低下し, Cyclophosphamide, Vincristin, Pirarubicin, Predonine 併用療 法を 3 クール行った.

\section{考 嘆}

非 Hodgkin リンパ尰はリンパ節以外の臓器からも 発生することが知られている、主な発生部位は消化管, Waldeyer 輪, 副鼻腔などで，稀には甲状腺，縱隔，皮 虐，骨，脳，眼窩，口腔，乳腺などである。

骨原発悪性リンパ腫は, 1939年 Parker ら゙により “primary reticulum cell sarcoma of bone"として初 めて報告されたが，その後，細網肉腫ではなく骨原発 のリンバ董であることが提唱され，現在に至っている. Freeman らの統計によると節外性リンパ腫1,417例 中, 骨原発は69例 (4.9\%) と少ない. 骨病変の部位に 関して, Phillips ら`゙は上腕骨, 大腿骨, 脛骨の順に多 く，長管骨とくに骨端部に多いと報告している.

胸壁原発の悪性腫場としては, 軟骨肉腫, 骨肉腫,
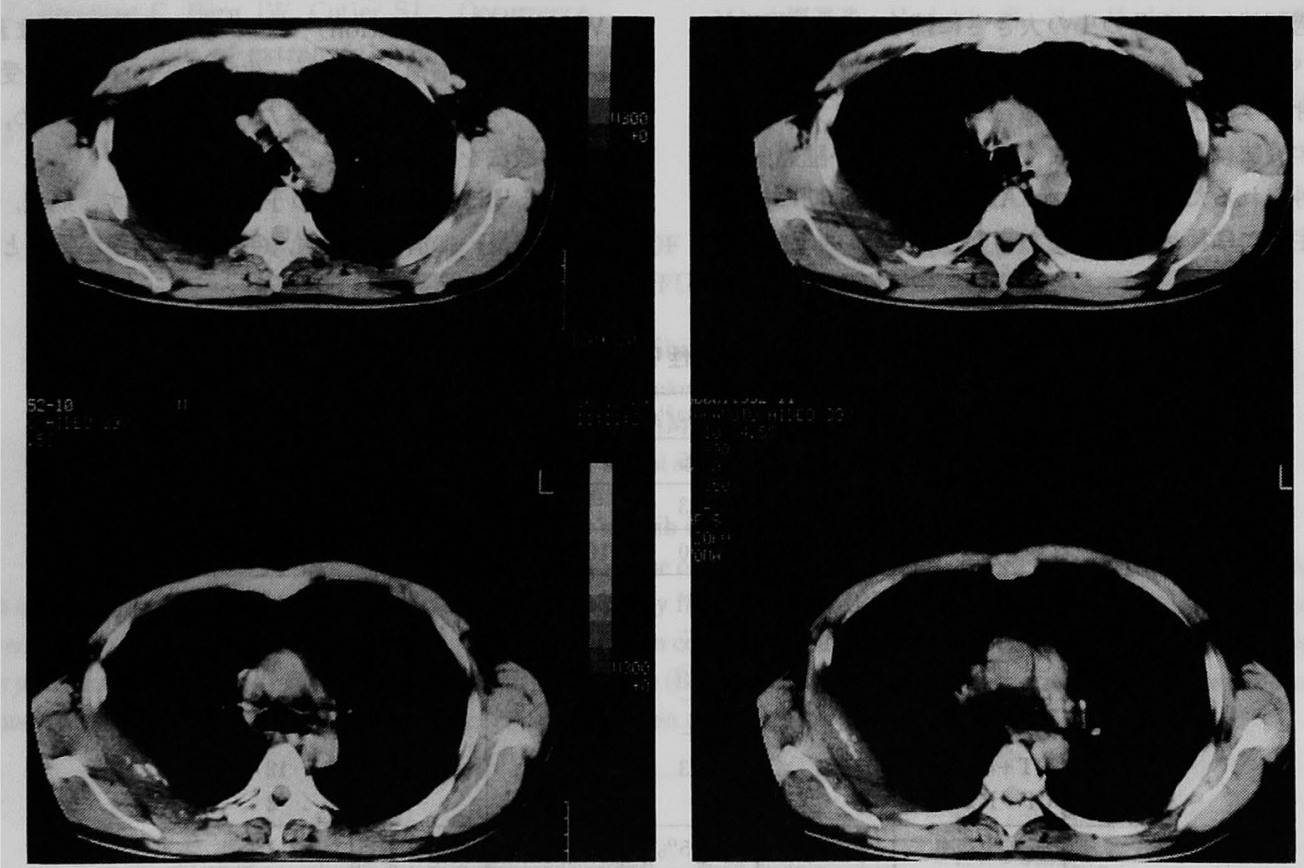

图4動注後の胸部 CT 像 


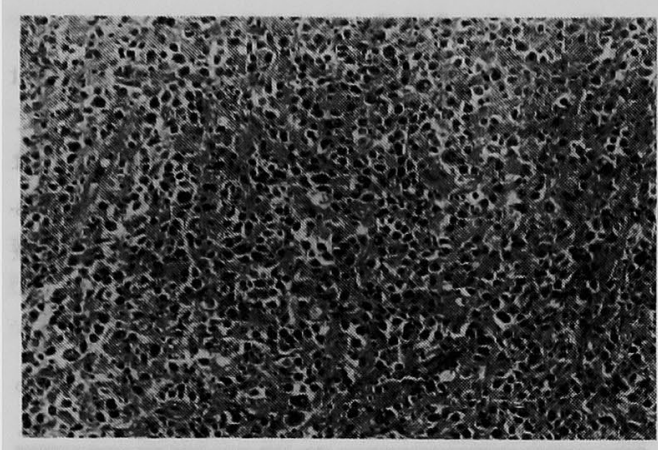

图 5 病理組䢂像（H.E 染色, $\times 100)$

Ewing 肉腫などが多く, 肋骨原発の悪性リンハ腫は極 めて稀であるが，鑑別診断の一つとして考虑しておか なければならない。

本症例は右胸部痛で発症し, 胸部 X 線で肋骨の融解 像を伴 5胸膜外腫瘤として発見された。画像上から助 骨原発の悪性腫湯が疑われたが，摘出するには胸壁の 欠損が大きく術後の呼吸障害が悆念されたため，まず 動注化学療法を試みた。針生検では組織診断が得られ なかったが, 骨肉瘇が強く箿われ，感受性の高い CDDP, ADR を右第 5 肋間動脈から注入したところ, 3 週間後には 3 分の 1 の大きさに縮小した。骨悪性り ン八腫に対する治療として, 手術療法, 放射線療法, 全身化学療法を併用した報告が多い（表 2）が，動注 化学療法は副作用が少なく，な拈かつ高い睡場内濃度 が得られるため, 特に Ann Arbor 分類の I 期に相当す る症例には極めて有效であろう。
骨原発悪性 リンパ腫の骨 X 線所見の特徵としては, 神藤らりによると，溶骨性変化を示すすのが $50 \%$ ，造骨 性変化が $25 \%$ ，混合性変化が $25 \%$ と様々で，他の骨腫 瘍との鑑別は困難である.MRI では，T2強調画像で凬 瘍は筋肉より高信号を呈するため, 腫瘍と筋肉は CT よりよく識別できる．血管も無信号となり腫掦と区别 できるが，骨軟骨との関係はCT の方が優れている ${ }^{10}$. このよ5に骨腫煬の存在診断, 他臓器との関係をみる のには MRI，CT は有力であるが，質的診断に関して は症例を積み重ねて検討する必要がある。

骨原発か否かについては，議論の分かれるところで ある. Dosoretz ら4は“悪性リンバ系細胞の骨内への浸 潤で，所属リンパ節や内臓には転移のないもの，また 隣接軟部組織への漫潤の有無は問わない”と定義して いる，本症例では骨周辺のリンバ組織より発生し骨内 浸潤を起こした可能性も否定はできないが, 主病変以 外にリンバ節の腫脹や腫煬性病变を認めず, 骨破壊が 著明で, 助間動脈より栄養されていることから, 助骨 原発の悪性リンバ畽と考学る。

組織学的には, 骨原発悪性リンパ腫は大部分非 Hodgkin 型であり，さらに細分類するとびまん型に属す る. 本症例も, びまん性大細胞型 B リンバ腫であった が,これは非 Hodgkinリン八畽の病理組織分類 (Working Formulation) では中等度悪性群に含まれ, 比較的急速な增殖を示すか，化学療法に極めて感受性 が高い(11).外科的に切除できた後も再発予防のため, 全 身化学療法を併用すべきと考える。

下山ら ${ }^{121}$ は B リンパ重の予後因子として, 病理, 病 期, 原発巣, 血清総蛋白値, 年龄の 5 因子が重要と報

衰 2 骨㩊性リンパ屋報告例

\begin{tabular}{|c|c|c|c|c|c|c|}
\hline & 報告者 & Dosoretz $z^{4}$ & 山口 & 石井6) & 横山? & 上田 ${ }^{8)}$ \\
\hline & 報告年 & '82 & '85 & ' 89 & '90 & '90 \\
\hline & 症例数 & 33 & 13 & 5 & 7 & 34 \\
\hline & 胁骨原発 & 1例 $(3.0 \%)$ & 0 & 1例 $(7.7 \%)$ & 0 & 5 例 (14.7\%) \\
\hline \multirow{4}{*}{ 治 } & OP only & 4 & - & - & 2 & 4 \\
\hline & RT only & 24 & - & - & - & 3 \\
\hline & CT only & - & - & - & 1 & 6 \\
\hline & $\mathrm{OP}+\mathrm{RT}$ & 1 & - & - & - & - \\
\hline \multirow{4}{*}{ 療 } & $\mathrm{OP}+\mathrm{CT}$ & - & - & - & 1 & 3 \\
\hline & $\mathrm{RT}+\mathrm{CT}$ & 4 & 13 & 3 & 3 & 12 \\
\hline & $\mathrm{OP}+\mathrm{RT}+\mathrm{CT}$ & - & - & 2 & - & 2 \\
\hline & 5 年生存率 & - & $37.5 \%$ & $20 \%$ & - & $57.1 \%$ \\
\hline
\end{tabular}


告している. 原哞栄に関しては, 胃, 甲状腺, Waldeyer 輪原発の B リンハ腫は予後が良く、リンバ節原発のも のがそれに続き，上記以外の節外䐘器原発のるのは最 す予啳が悪い.上田ら量の報告によると，骨原発例の 5 年累耤生存率は57.1\%で, Working Formulation に基 つく組織学的悪性度とよく相咸する.

骨悪性リンバ腫の診断においては，正確な臨床病期 の決定と組織学的悪性度の検討が重要であり，手術療 法，放射線療法，動注及び全身化学療法を併用した集 学的治寮を試みることで, 予後の改善が期待できる。

本症例は術後10カ月を経過した現在，転移再発の兆 侯を認めず健在である。

\section{結䨗}

右第 5 助骨に発生した悪性リンパ腫の 1 例を絓験し たので文献的考察を加えて報告した。

なお，本症例の報告において闺山大学放射線科栄 勝美

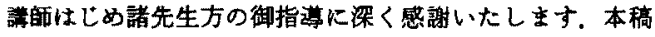
の要旨は第53回日本臨床外科医学会総会（1991年11月，德 島)で発表した。

$$
\text { 文献 }
$$

1) Parker F, Jackson H : Primary reticulum cell sarcoma of bone. Surg Gynecol Obstet 68: 45 $-53,1939$

2) Freeman C, Berg JW, Cutler SJ: Occurrence and prognosis of extranodal lymphomas. Cancer $29: 252-260,1972$

3) Phillips WC, Kattapuram SV, Dosoretz DE, et al : Primary lymphoma of bone-Relationship of radiographic appearance and prognosis-. Radiology 144 : 285-290, 1982

4) Dosoretz DE, Raymond AK, Murphy GF, et al: Primary lymphoma of bone. The relationship of morphologic diversity to clinical behavior. Cancer $50: 1009-1014,1982$

5）山口秀夫，井須和男，姥山勇二他：骨原発悪性りン 八腫の13例，整形外科 $36: 1515-1522,1985$

6) 石井 猛, 遠藤富士乗, 鬼頭正志他 : 骨原発悪性 y ンハ:尰 5 例の治療経験，整形外科 $40: 507-512$, 1989

7）横山良平，篠原典夫，横山薄一郎他：骨原発悪性り ンパ腫の 7 例一兔疫組化学染色を用いた㭘討 一，中部整㷋誌 $33: 1297-1299,1990$

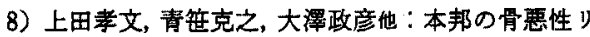
ンバ腫の臨床病理学的検討, 整形外科 $41: 1657$ $-1664,1990$

9）神藤佳孝，青木康竞，小松原良雄他：整形外科にお

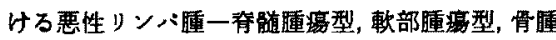
得型について，中部整项誌 $32: 448-450,1989$

10) Glazer HS, Niemeyer JH, Balfe DM, et al : Neck neoplasm-MR imaging part I. Initial evaluation一. Radiology $160: 343-348,1986$

11）大步泰亮：Hodgkin 病, Non-Hodgkin リンバ睡 の治療法の選択の原理, 内科 $68: 260-265,1991$

12）下山正徳，太田和雄：Bソンパ畽の予後因子と治 廋， 日網内系会誌 $27: 329-342,1987$

\title{
A CASE OF MALIGNANT LYMPHOMA OF THE RIB SUCCESSFULLY TREATED WITH INTRAARTERIAL INFUSION CHEMOTHERAPY
}

\author{
Yasuhisa OKAMOTO, Takahito YAGI, Shinya OHE and Masaaki HASHIMOTO \\ Department of Surgery, Fukuyama Daiichi Hospital \\ Fumiyuki INOUE, Yasuaki KAMIKAWA and Kunzo ORITA \\ First Department of Surgery, School of Medicine, Okayama University
}

A rare experience with malignant lymphoma of the rib is reported in the light of the related literature.

A 39-year-old male patient visited our hospital because of right back pain. The patient was diagnosed as having a malignant tumor of the right fifth rib from a chest X-ray film, CT and MRI. Intraarterial infusion chemotherapy reduced the tumor size remarkably and a radical operation could be undertaken. Histopathological findings showed a malignant lymphoma of the bone, diffuse large cell type (B). Adjuvant general chemotherapy was also performed and the patient feels well without any recurrence, as of ten months after the operation. 